\title{
Shakespearean and Brechtian Drama and Theatre: An Audience Response Perspective
}

\author{
Vishal Joshi' and Shakuntala Kunwar ${ }^{2}$ \\ ${ }^{1}$ Doctoral Candidate, Department of English, HNB Garhwal University (A Central \\ University), Srinagar-246174, Uttarakhand (India),Email: joshi.vishal84@gmail.com, \\ ORCID: https://orcid.org/oooo-0oo3-1922-2677 \\ ${ }^{2}$ Professor, Department of English, HNB Garhwal University (A Central University), \\ Srinagar-246174, Uttarakhand (India), Email: shakuntalarauthan@gmail.com
}

\begin{abstract}
Shakespearean Dramatic theatre and Brechtian Epic theatre represent two divergent paradigms in the field of genre-drama. The plays falling under these two varying paradigms invite their readers or audience to learn to approach them by adopting a different theoretical perspective or critical stance. As per Martin Esslin "human capacities can change through time: human beings may learn to adjust themselves to new ways of perception ..., and gain practice in accepting new ways of seeing both reality and art" (15). In the proposed study, the two plays chosen for comparative analyses are Hamlet by Shakespeare and Mother Courage and Her Children by Brecht: the former one centring on empathy, and the other one on alienation. Of the two paradigms discussed in the present study, in one type, admittedly, an emotional catharsis occurs and the second theoretically disclaims emotional catharsis.
\end{abstract}

Keywords: illusion, empathy, catharsis, hamartia, probability, bisociation, introjections, projection, verfremdungseffekt, alienation effect, leichtigkeit, spass, laconic language, Hegel's dialectics.

The term 'audience', in this paper, is intended to cover the reader of a play also. 'Response' may be understood within the parameters of its being collective. It brings into focus the generalised impression of the point of view as realized through the medium of the play. The type of audience response elicited by a play bears direct relation with the type of the pattern of the play. When the pattern is common to a number of plays, it becomes a paradigm of the pattern. Furthermore, as per Toropov, "[p]lays are meant to be experienced in person" (7), whether we read them or watch their live performance. Scholars hold the view that the two dominant ancient dramatic forms - tragedy and comedy "have always been complementary aspects of the [dramatic creative] impulse which creates theatre" (Hirst, Preface xi).

The components of tragedy have undergone considerable change over a period of time, and certain elements of the Aristotelian concept of tragedy have been variously modified by latter-day dramatists in the Western tradition of drama and theatre. The basic common denominators of tragedy have, however, continued the same as mathematical constants. Aristotle made use of the term 'catharsis' in the sixth chapter of Poetics and made it the essential function of a successful tragedy. Shakespeare's tragedies broadly follow the schema generalized by Aristotle.

(C) AesthetixMS 2021. This Open Access article is published under a Creative Commons Attribution Non-Commercial 4.0 International License (http://creativecommons.org/licenses/by-nc/4.o/), which permits non-commercial re-use, distribution, and reproduction in any medium, provided the original work is properly cited. For citation use the DOI. For commercial re-use, please contact editor@rupkatha.com. 
Shakespeare's writing continues to captivate his audiences for the preceding four centuries. As per Toropov, his "plays are filled with action, his characters are believable, and the situations they find themselves in are exactly like our own" (2), as if holding a mirror to our unruly "greed, power, ambition, love, jealously, old age, racism" (2). In his fictional creations, Shakespeare's genius magnifies aspects of our own personality, for instance "in the 'overthinking' Prince of Denmark, the jealous Moor of Venice, the noble Cordelia ...." (2); and that too in the language, which is acknowledged as 'downright thrilling'.

In the theatre capital of London of the 1590s, Shakespeare was deeply fascinated by the dramatic illusion of the theatre. He was there "constantly exploring and referring to the world of theatre - audience, scene, role-playing, the Globe itself - and exploring the gap between appearance and reality" (Papp \& Kirkland 118). His drama constantly reflects "on its own nature, prodding his audience to think about the nature of the dramatic event, they are sharing, as in Hamlet's playwithin-a-play [known as 'mouse-trap']" (ibid.). Shakespeare's conception of good acting is that what resembles natural and life-like. Hamlet's instructions to the players underscore the purpose of acting "to hold ... the mirror up to nature" (Ham. III. ii.).

Shakespeare is said to be "a product of his times" in respect of "his far-flung borrowing". Not-with-standing that, "as in so much else, he flew high above his contemporaries. Shakespeare's ultimate source was the broad spirit of his age" (Papp \& Kirkland 155). This was so because he "imbibed the rich Elizabethan atmosphere as he walked the streets of London, and it was this atmosphere that he converted magically into theatre" (ibid.).

The peculiar features that distinguish Shakespearean tragedy are not born out of a deviation from Aristotelian theory but are, so to say, additive, and are owing to comic episodes, improvisational entertainment, ritual elements, and the like, based on dramatic need; as also because of the different point of view of the dramatists. For their aesthetic appeal, Shakespearean romantic tragedies primarily depend on empathy. The action of this type of plays allows the audience to fill up details by the use of its own imagination, and this, in turn, creates illusion. Goethe recognized this peculiarity by the bare Elizabethan stage as far back in 1826 , by which the audiences were free "to imagine as many paradises and palaces as they pleased on the empty stage" (Goethe cited by Willett 99).

The play Hamlet, under reference, brings about an emotional catharsis, and hence would imply a close, subjective involvement of the audience through an act of empathy and resultant catharsis marked by a sense of release of tension, relief, and an acceptance of the fall out of the dramatic conflict. The action of Hamlet is divided into two major segments after Aristotle: complication and unravelling (Poetics ch. XVIII translated by Butcher 65). The dividing point in Hamlet in this context is the killing of Polonius (III, iii). Hamlet satisfies the qualifications of the typical tragic hero of Aristotle (Poetics chaps. XIII and XV pp. 45 \& 53). Hamlet's qualities of character endear him to us. The personality of the protagonist is unfolded to us by his own comments, by comments made by other characters concerning him, and by his behaviour in situations contributing a frame of reference.

The principal ingredient of the protagonist's character in this play is patterned after Aristotelian dictum hamartia, the tragic flaw, variously described as indecision, melancholy, or a moral scruple. The essence of the tragic flaw, at the level of identification, shows that the protagonist is, for all his superior traits, like us, one who is not perfect or absolute. But he holds a high station whereby the audience/reader perceives him as significant, and his situation of consequence. These factors grippingly invite the attention of the spectators/readers. 
The audience or reader is imaginatively transported to the 'make-believe' world of the play and identifies with the protagonist on account of his likeness to itself, and also owing to the character's being drawn larger than life, and the like feels gravitated towards the protagonist and begins to view with sympathy and concern the problem he encounters.

Shakespeare, however, does not present Hamlet as a unified character, but focuses upon his several diversities. A sense of contrariety results, at times. In the course of action, the playwright shows the character of Hamlet. Since the action moves along the lines of probability, this feature both of character and situation aids the development of illusion. The episodes and actions appear to be natural, and at times obvious. Owing to the operation of probability, no part of the character or action distracts the audience from the plan of action. The audience is cajoled into perceiving the action within the illusion-building framework of the Romantic plays, and consequently, the 'distance' between the action and the spectator is greatly reduced.

The conditioning force of the device of probability is such that the audience is not called upon to make use of its own discrimination. Since the sympathies of the audience are for the protagonist, the bond of the identification is strengthened and 'empathy' becomes operative. Coleridge calls this state a 'willing suspension of disbelief' and thereby, in a sense, the audience also suspends interposing its own judgement.

Borrowing Arthur Koestler's concept of 'bisociation' one may better explain the point. According to him 'bisociation' is a "condition in the mind of the audience where the spectator knows in one compartment of his mind, that the people on the stage are the actors", and at the same time, takes the illusion to be real. The bisociated mind operates in two or more separate frames of reference and can easily switch from one frame of reference to that of the other. It differs from the usual single-minded thinking process and represents a double-minded or multi-minded activity. One frame of reference can be associated with the self-assertive tendencies and the other with the self-transcendent tendencies of man.

In such a situation the state of the audience depends upon whether the self-assertive tendencies are subordinate to the self-transcendent, or vice versa. Koestler takes the examples of Hamlet and shows the operation of illusion in its primary effect of "transporting the spectator from his bed-sitter in bay water to the castle of Elsinor ..." (308). Illusion makes us perceive the hero as Lawrence Oliver (Oscar 1948, Best Actor for Hamlet's role), for example, and Danish prince Hamlet at one and the same time. The one becomes the other depending upon how we focus attention from one to the other.

For example, Shakespeare through Hamlet's pointing out a non-existent cloud to Polonius, make the audience see a cloud, through illusion. And the cloud seen is not a static image but a dynamic one, first resembling a camel, then a weasel, and finally a whale (Act III, sc. ii. 11. 360-365). But what if one of the spectators, looking at the ceiling, should question, "but where is the cloud?" This would debunk the illusion. Brecht makes use of such devices in order to debunk illusion when it suits its purpose.

In the plays of Shakespearean type, the audience does not perceive the action and its impact upon the protagonist by analogous perception. Rather, the spectator is one with the protagonist and actually feels the impact of the situation on character, by 'projection' and 'introjection', borrowing the terms from psychoanalysis. It is held that through projection we impose our feeling on things that lie outside ourselves, which by themselves do not qualify for those qualities. For example, we project our sense of pain to the tree being hacked when we say that the tree must be experiencing pain when hacked. Introjection is meant to signify the reverse, for example, when a 
cyclist loses his balance we make body adjustments watching him from far away, in an attempt to counterbalance him. Thus, projection and introjection form the basis of our perceptual understanding.

In Shakespearean tragedy, though initially, the bond between the spectators and the characters is one of sympathetic identification, which is associative in quality, the shift to a position of empathy results through the process of bisociation. Thus, empathy is a state of the bisociated audience, related to that part of consciousness, which is predominant over the normal. We may equate this with supra-personal perception, which is marked by self-transcending in nature, whereas the normal is self-assertive by contrast.

In a sense, in Shakespearean tragedy the audience is firmly in the grip of the dramatist, who works in absentia, through the psychological control imposed by the pattern of the play, drawing forth predetermined responses. The devices of probability, illusion, bisociation, and empathy place the audience in a state resembling a trance - the magic of the stage. Broadly, this is the mode of communication in Shakespearean dramatic theatre. Such is the impact of illusion induced world of the 'make-believe' which is expressed in the words: "A drama is a work of art, a contrivance for imposing upon the spectator, causing him to take no account of actual time, place, and circumstances, making him almost forget that he is in play-house" (Ingleby 250).

Back to storyline, Ophelia's distraction (Ham. IV. v.) leads to another emotional crisis in Hamlet. The cause of this crisis is, however, traced to Claudius. Since her distraction would shock Hamlet, who is now absent, the audience, in turn, responds, both on account of Hamlet and of itself. Ophelia's madness apart, the songs she sings:

He is dead and gone, lady,

He is dead and gone

At his head a grass-green turf,

At his heels a stone.

White is shroud as the mountain snow... (11. 29-32, and 35)

It brings the audience to tears. Firstly, it is because the song suggests that Hamlet has died, in the context of unresolved tension. Secondly, that Ophelia's feelings are introjected into the audience. No news of Hamlet still. The action goes on and the audience discovers that Hamlet now has another enemy, Laertes. The death of Polonius and the mental breakdown of Ophelia are seen owing to Hamlet. In keeping with the revenge motive of the action, the point runs home. As Laertes turns his wrath upon Claudius, there is a sense of relief. The spectator would enjoy seeing Claudius suffering.

The long-standing tension concerning Hamlet and England is resolved (in Act IV, sc. vi.). This scene makes powerful use of illusion. What transpires on the high seas is not 'staged'. It is reported through Hamlet's letter to Horatio. The audience, however, sees the action - ships, pirates, sea, and all. Hamlet must now face, both, Claudius and Laertes. But well, the audience can 'wish' all problems away.

The incidental deaths of Guildenstern and Rosencrantz also form a link to the pattern. The next link of the pattern, constructed by the dramatist, is seen as the mechanization of the doubledealing hypocrite, Claudius. To the knowledge of the audience, the fencing match with the 
doctored weapon is a 'trap' that is fool-proof. As a second measure to this end, there is the poisoned drink meant for him. To top it all, the terms set out by the King - should Hamlet win he drinks the cup, and if he loses, he dies - carry the paradoxical logic of 'heads I win, tails you lose'. All that while, Hamlet has not the faintest idea of the fraud he is being subjected to. The audience bangs upon its capacity to wish, however.

The hopes of the audience are shattered this time. The wishes do not mature in the usual way. They, instead, are frustrated, that being the tragic moment. Hamlet is mortally wounded (Act V, sc. ii.) by Laertes, and Laertes by Hamlet, after the change of foils. The Queen unknowingly drinks the 'poisoned cup', and Hamlet, before dying, kills Claudius. The nomination of Fortinbras for the crown is the nominal end of the action.

At the end of the play, the pattern yields abstracted information to the audience. Each link of the pattern announces a death - that of King Hamlet followed by that of Polonius, Guildenstern and Rosencrantz, Ophelia, the Queen, King Claudius, Laertes, and that of the hero, Prince Hamlet, in that order. Laertes's last words, 'Mine and my father's death come not upon thee / Nor thine on me!' encourages thought.

The audience, at the close of Hamlet comes to face eight deaths, if we do not count King Hamlet in. the vision That Shakespeare was out to convey to the audience has been discerned by Kitto whom we quote:

In Hamlet, Shakespeare draws a complete character, not for the comparatively barren purpose of 'creating' a Hamlet for our admiration, but in order to show how he like the others is inevitably engulfed by the evil that has been set in motion, by the killing of King Hamlet, and how he himself becomes the cause of further ruin. (157)

The pattern of the play clearly brings out the message of Shakespeare, that evil ruins itself along with the good and the indifferent. Moreover, Hamlet's tragedy makes us learn "that even his own massive intellect cannot allow him to control his destiny or reverse the 'diseases' of passing time" (Toropov 124).

Bertolt Brecht (1898-1956), a Bavarian dramatist, is said to be one of the theatrical pioneers of the early twentieth-century who "gave dramatic definition to the challenging new philosophical and political approaches of the inter-war period". Brecht was a leading voice of the "committed political theatre consequent upon [his] conversion to Marxism in the late 1920s"; also that he "was writing in the early 1930 s to combat the rise of Nazism, but he was powerless to halt the success of Hitler and its consequences" (Hirst 101). Brecht in his notes to Mahagonny claimed that "modern theatre is Epic Theatre' and he drew a table of differences to underscore its 'shift of accent' from the conventional Dramatic Theatre (notably tragedy), which is reproduced as under:

\begin{tabular}{|l|l|}
\hline \multicolumn{1}{|l|}{ Dramatic Theatre } & Epic Theatre \\
\hline - Plot & $\bullet \quad$ Narrative \\
\hline - $\begin{array}{l}\text { Implicates the spectator in a stage } \\
\text { situation }\end{array}$ & $\bullet \quad$ Turns the spectator into an observer, but \\
\hline - Wears down his capacity for action & $\bullet \quad$ Arouses his capacity for action \\
\hline - Provides him with sensations & $\bullet \quad$ Forces him to take decisions \\
\hline
\end{tabular}




\begin{tabular}{|c|c|}
\hline - Experience & - Picture of the world \\
\hline - The spectator is involved in something & - He is made to face something \\
\hline - Suggestion & - Argument \\
\hline - Instinctive feelings are preserved & - Brought to the point of recognition \\
\hline $\begin{array}{l}\text { - The spectator is in the thick of it, shares } \\
\text { the experience }\end{array}$ & - The spectator stands outside, studies \\
\hline - The human being is taken for granted & - The human being is the object of inquiry \\
\hline - He is unalterable & - He is alterable and able to alter \\
\hline - Eye on the finish & - Eye on the course \\
\hline - One scene makes another & - Each scene for itself \\
\hline - Growth & - Montage \\
\hline - Linear development & - In curves \\
\hline - Evolutionary determinism & - Jumps \\
\hline - Man as a fixed point & - Man as a process \\
\hline - Thought determines being & - Social being determines thought \\
\hline - Feeling & - Reason \\
\hline
\end{tabular}

(Brecht cited in Intro. by Chatterji xxv-xxvi)

Brecht is, thus, said to have rejected traditional European Theatre believing "that theatre induced emotional participation by the method of suggestion and emotional manipulation; that the catharsis through terror-and-pity led to a 'calm of mind, all passion spent', which was the opposite of a critical response and hindered in social intervention and transformation." (Chatterji xxvi)

Bertolt Brecht criticised illusionistic dramatic theatre of Shakespearean type for its "heightening of the illusion in setting, along with a 'magnetic' manner of acting [which] gives the spectator the illusion of being present at a fleeting, fortuitous 'real' event" (Brecht cited by Willett 10o), and this creates such an impression of naturalness that one can no longer interpose one's judgement. Accordingly, illusion, empathy, and catharsis become the paradigmatic features of Shakespearean romantic tragedies for their dramatic, theatrical effect.

Brecht's dramatic form employs devices in order to achieve greater distance which he called verfremdungseffekt or 'alienation effect'. While Shakespeare's practice and Aristotle's dictum both aim at establishing an emotional convergence between the spectator and the protagonist, where the gain and losses of the protagonist become those of the spectator (imaginatively and emotively) 
as well, Brecht's aim is to spell out divergences between them. Brecht's dramatised parables, on the contrary, seek to staunch pity in an understanding of wider social and political issues.

Referring to Brecht's essentially comic technique and serious (even didactic) aim Hirst's comment deserves notice: "his rejection of naturalism and tragedy in favour of Epic Theatre resulted in a mixed genre that had immense critical potential and which has developed in the contemporary theatre into a vital and important variation of tragicomedy" (109).

In the genre drama, as per Hirst, Brecht's comic method purposively combines with effectiveness the devices of leichtigkeit (lightness of touch) and spass (fun). He feels that modern political drama tends to ignore them at its peril. In this connection, Hirst cites Brecht's argument in Messingkauf Dialogues (p. 95) that a "theatre that can't be laughed in is a theatre to be laughed at". One, no doubt, notices the comic vein in Brecht's earlier works, but after his conversion to Marxism "comedy is handled with greater subtlety in his subsequent dramatic writings" (Hirst 107).

Brecht's Epic Theatre brought in a new concept enriching the heritage of genre drama to function as "a [new] mixed-genre which had immense critical potential and which has developed in the contemporary theatre into a vital and important variation of tragicomedy" (ibid. 109). All the many changes that Brecht made in the earlier practice of drama produce certain effects. Alienation becomes the mainstay of Brechtian drama. His use of laconic language alienates emotion from thought. The use of laconic language divests it from its capacity to act as a vehicle of emotion - the character using it does not express its own emotion, nor does it induce in the audience.

A further device that secures this end is the use of past tense by the actor during rehearsals. The dialogue in the past tense alienates the act from itself. While the action is 'present', the dialogue gives it a dimension of 'past tense', and the time gap spells discord. The action seems to be a reenactment of the already happened past event and dialogues assume the vein of the narrative. The impression is ballad-like and belongs to epic proper. Illusion, instead of being fortified, is weakened.

The aura of a narrative is also supplied by the use of the third person. At times, the narrative also includes lines that form the part of stage directions. This is done, however, with calculated restraint. As a result of the use of these devices, the audience sees both the actor and the character being represented. Because the actor alienates himself (by enacting/impersonating from without) from the character, the audience does not identify deeply with the character, for the illusion is not sufficiently strong enough to allow such identification. The audience observes the character instead of identifying with it.

In Shakespearean theatre, causal sequential events develop along with the lines of probability. Each subsequent event is linked up with an earlier event. Things happen exactly as they ought to be, at least until the tragic moment. In the Brechtian theatre 'probability' is not made use of in this manner. Episodic events are disconnected and occur in contrast to each other. As soon as a situation develops it presents an open option to the character. The audience, at times, may prefer that the character take a particular option, but the character opts for the other.

Thus, there is a gap between the views of the character and the audience. The audience now works out why the character took the 'not-so-obvious option' and sees the dramatist's point of view. Brecht gave up Aristotelian 'probability' in favour of Hegel's 'dialectics'. An event acts as a 'thesis', in which the character acts according to his choice or limitations. This choice differs from that of the audience, or the audience is not taking the limitations into consideration. What the character does becomes the 'antithesis'. The 'synthesis' results from the audiences' understanding the reasons for the character's choice. 
To illustrate this point, we may draw an example from Brecht's Mother Courage. Honest Swiss Cheese is brought in dead on a stretcher at the close of scene 3, which is one of the tragic incidents of the play. The audience knows how much Mother Courage cares for her children. Yvette has stirred the emotions of the audience by telling Courage, "Eleven bullets they gave him, that's all". She, at the same time, warns Courage not to own Swiss Cheese by identifying him when his corpse is brought in. Since an appeal has been made to the emotional half of the audience, the audience assumes that Courage may recognize Swiss Cheese. But she does not. With this, the audience shifts towards reason and considers the warning remarks made by Yvette. The realisation dawns upon the audience, particularised by Courage's options, that this is what war does to people. The point planted by Brecht runs home with the audience.

Expressing his views on illusion, Brecht wrote, "the illusion created by the theatre must be partial one, so that it can always be recognised as illusion" (cited by Eric Bentley 100). Brecht, thus, uses primary illusion, and where the need arises he uses more powerful illusion. Examples occur in scene 11. The peasant climbs atop the roof and looks outside the stage and says, "something moving in the wood. Can see something down the quarry. And there are men in the armour in the clearing. And a gun. That's at least a regiment" (Mother Courage). The woods, the quarry, the clearing, and the gun, are thus left to the audience for imaginative visualization. Brecht also uses auditory signs which are produced offstage and signify the fire of the town's canon. The place being depicted on the stage is the product of illusion, as well. Brecht admits: "there is no objection to this, because there must be some stirring of poetry in the soul of the spectator if such an illusion is to come about" (ibid.).

Mother Courage employs stimuli that are divested, theoretically, of emotional colour. The appeal is time again, to audiences' faculty of reason, not to its emotional sensitivity. Instead of putting events into the straightjacket of probability, Brecht presents open options to the characters and makes the audience think about the option exercised by the character. The modalities of the two paradigms (Shakespearean and Brechtian) differ on this count, and so do the responses of the audience. In Brecht emotions generated at a particular place in the play are blocked by attracting the attention of the audience to the attitude of reason.

All the same, the issue from which the emotion sprang at first is touched upon this time more remotely and this second exercise weans the emotion away from the spectator. It is now viewed in a different realistic logical frame of reference. For example, the honesty of Swiss Cheese is voiced time and again. When he comes to his tragic end, ironically, due to it the concern of the audience is shifted to whether Mother Courage will act with her shrewd practical business sense or land herself in troubles by succumbing to her maternal instinct.

The death of Swiss Cheese is shelved for the time being. It is re-invoked in a displaced manner in scene 9, through analogy. This is done through the third stanza of the song that is sung by Courage and the Cook:

\section{You heard of honest Socrates}

The man who never lied:

They weren't so grateful as you'd think

Instead the rulers fixed to have him tried

And handed him poisoned drink. 
It's honesty that brought him to that state.

How fortunate the man with none!

The debunking song, thus, does re-invoke the emotion pertaining to the tragedy of Swiss Cheese. It foregrounds an important point of view: that honesty does not pay during war, all values are out of place in times of war, and war has its own code as peace has its own. When war comes, only those who can adopt the related code survive; those who cannot, suffer. This view-point is fortified through the case of Eilif. Brecht has made him perform the very same act, once during the war which makes a hero of him; the other time in conditions of a short-lived peace which spells doom for him.

There is, however, an inconsistency between the theory and practice of Brecht. He rules out empathetic identification in his plays but admits that audiences were especially stirred by the drum scene in Mother Courage. The well-known 'drum scene' uses stimuli that address themselves to the emotional faculty of the audience, rather than to the sense of reason. Brecht by making Kattrin dumb divested her from being able to use a language spoken sardonically. The audience was left with no other alternative but to try to understand Kattrin's actions and gestures intuitively, and with the aid of imagination.

The initial sense of pity aroused on account of Kattrin's being dumb, which is a sort of denial, hence tragic. Her harmless self-transcending actions appeal to the emotional part of the audience. The war gives her ugly scars and this increases the sense of her denial. The drum that war gives her is used by her at a time when the other characters, the peasant and his wife, escape to prayer instead of resorting to action. In such a dire situation Kattrin, though stone deaf, speaks through the agency of the drum and succeeds in rousing the sleeping town. In return, she is given death.

Empathy is clearly built up, whether Brecht intended it or not. The justification given by him is rather tongue-in-cheek. Brecht's attitude to Kattrin on this score is implicit. After her death and the fading away of the emotional tone, he reinstates the feeling through a strong analogy. In the song in scene 9, Brecht observes that virtue has no place in times of war, and in stanza 1 he makes an ironic comment on wisdom in relation to man's decision to wage war.

Accordingly, Eilif's courage is talked about by displacing it to Caesar in stanza 2, and thereafter the honesty of Swiss Cheese is brought into vision in stanza 3. Brecht, however, presents an analogy of Kattrin in the fourth stanza and equates her with unselfish Saint Martin, who "couldn't bear to see / His fellows in distress" (Mother Courage sc. 9), and the audience now recounts the 'unselfishness' that brought Kattrin to her tragic end. The poetic prologue used by Brecht "in 1950 to tell German children the story of Mother Courage", leaves hardly any scope for disagreement in this context. We quote the last stanza of the short poem, as cited by Willett and Manheim (xxi-xxii): "Her first son died a hero / The second and honest lad / A bullet found her daughter / Whose heart was too good" (ibid.).

Accordingly, one may say that the audience response in respect of the role of Kattrin is an intrusion of the theoretic 'Shakespearean' responses in the overall 'Brechtian' responses. It is an overlay or in other words such response appears to be 'unintended', 'unintentional', they being indeterminate.

To sum up, Shakespearean Dramatic Theatre and Brechtian Epic Theatre represent two divergent paradigms in the field of drama and theatre. Shakespearean tragedy is composed of particular incidents on which dramatist places selective emphasis. The dramatist underscores these 
incidents, as they are, and their meaning also carries the emotional colour. This is so because the play is designed to evoke an emotional response, and subsequently an intellectual appeal that unfolds the vision of the dramatist.

A Brechtian tragedy along with its comic method intends to convey the message of the dramatist directly, and in its attempts to convey the vision of the dramatist it does not rely on the evocation of the emotions as the first charge. Incidental emotions may arise, and the audience may develop deep feelings, but in this case, feelings result from meaning, not meaning from feeling as is the case with Hamlet. Therefore, the pattern of Mother Courage is more diffused and it is meaning that is to be conveyed, emotional high spots are handled with great care. Emotions arise and are stilled by shifting the emphasis to the frame of reference of logic. The stimulus that triggers off the emotion is again presented in a different light, where it is rationalized. Any undischarged emotion is leached out by the use of analogy, where the meaning is emphasized upon and the audience response becomes a marked matter-of-fact assessment of the situation - a way of the world of the play.

The emotional response of the audience to Mother Courage is diffused by limiting the incidents in such a way that she is denied her children and her opportunity to settle down with the cook. But her death is not on the charts. The audience does not form an empathic relationship with Courage, Swiss Cheese, or Eilif, and Brecht would wish for none with Kattrin as well. The discontinuity between scenes also has the effect of making the audience objective and selfconscious. Courage's inability to live up to her sentiments, if there be any, blocks the rise of audience emotions.

The emotional impact of Eilifs death is reduced by Brecht's ironic gesture of Mother Courage's ignorance about his death. The pattern consists of the three incidents of death, but the handling is different, as the tragic incidents are underplayed. No doubt, the death of Kattrin does not fit in with this scheme, but it is atypical, and not Brechtian. Swiss Cheese dies, not so much on account of his honesty, but owing to an error of judgment of Mother Courage. She bargained too long. Eilif's bravado, his normal trait, is suitable to wartime pursuits, but not to peace, and he cannot shuffle his code. And war is obliviously no place for the practice of universal love, Kattrin's trait.

The tragedy of the aforesaid three is occasioned by the same cause, war, and it is war alone that is to blame for it. This, verily, is the message of the play, and though Mother Courage fails to learn it, the audience does not do so. The audience develops a strong feeling of rejection of war through this Brechtian vision. The code of behavior of peace is unsuitable to the times of war. Those who cannot find a substitute code must suffer. Courage is not conscious of the two separate codes but somehow tides through.

Shakespeare's dramatic genius aided him amazingly to recast his sources and thereby create gripping drama. In this connection the view of Papp and Kirkland is worth notice:

Shakespeare approached his sources not as a scholar but as a playwright. Although he had plenty of facts at hand, his goal was dramatic truth. Everything he read, everything his absorbent mind took in, was shaped and molded to the needs of the theatre. The question at the back of his mind [was always] what will work on the stage? (159)

In his study of tragicomedy, Hirst argues that Shakespeare deserves the credit of "extending the potential of tragedy by making us aware that his protagonists are human", and he by "showing the gap between heroism and more down-to-earth concerns ... expands the range of our emotional sympathies for the characters" (42). He further adds that "Shakespeare anticipated (and influenced) 
Brecht's concept of Epic Theatre in his refusal here to draw the audience into a straightforward cathartic experience" (41). He acknowledges Shakespeare's capability "in appealing at one and the same time to our emotive and rational faculties" (41). Accordingly, for his contrasted theatrical form, Brecht is more likely to have been indirectly influenced by his grand predecessor, Shakespeare. In this connection one may recall the remote effect of Harold Bloom's concept of the 'anxiety of influence'. In Messingkuof Dialogues (p. 47) Brecht is reported to have said: "sorrow is hostile to thought; it stifles it; and thought is hostile to sorrow" (ibid.). In literary parlance, Brecht is acknowledged as the dramaturge who revolted against the then 'prevailing paradigm' and to chart for him a different trajectory to move.

\section{References}

Aristotle. (2007). Poetics. (S.H. Butcher, Trans.). Aristotle's Theory of Poetry and Fine Arts. Rpt. ed., Kalyani Pub..

Bentley, E. (1970). 'Bertolt Brecht' in the Reader's Encyclopedia of World Drama. Edited by Gassner, John and Edward Quinn, Methuen.

Chatterji, R. (1992). Introduction \& Notes on Mother Courage and Her Children: A Chronicle of the Thirty Years War. Translated by Eric Bentley. $3^{\text {rd }}$ Impression. Oxford UP.

Esslin, M. (1995). The Field of Drama: How the Signs of Drama Create Meaning on Stage and Screen. Rev. ed., Methuen.

Goethe, J. W. V. (1980). Cited in 'Notes and Variants' Mother Courage and Her Children. (J. Willet, Trans.). Eyre Methuen.

Hirst, D. L. (1984). A Tragicomedy (The Critical Idiom, 43). Methuen.

Ingleby in Hamlet. (1963). A New Variorum Edition of Shakespeare. Edited by Horace, Howard Furness, Dover.

Kitto, H.D. (1970). "Hamlet” in Shakespeare Criticism 1935-198o. Edited by Anne Ridler, Oxford UP.

Koestler, A. (1971). The Act of Creation. Hutchinson, 1964; MacMillan.

Papp, J., \& Kirkland E. (1988). Shakespeare Alive!. New York: Bantam Bks.

Toropov, B. (2001). Shakespeare for Beginners. Orient Longman.

Willett, J., \& Manheim R. (1980). In 'Introduction' to Brecht's Mother Courage and Her Children. Eyre Methuen. 